\title{
Geo-Electrical Investigation for Groundwater Potential of Ihievbe Ogben, Edo North, South Western Nigeria
}

\author{
*11SALAMI, SA; ${ }^{2}$ OGBAMIKHUMI, A \\ "Department of Geology, University of Benin, Edo State, Nigeria \\ Corresponding Author Email: sikiru.salami@ uniben.edu
}

\begin{abstract}
This study was carried out within Ihiebe Ogben community in Akoko Edo LGA, Nigeria to investigate the ground water potential of the Basement Complex rocks using Vertical Electrical Sounding (VES) that deploys Schlumberger Array configuration. Evaluation of hydrogeological parameters shows fractured/ weathered basement thickness, resistivity values of the fractured basement, overburden thickness and basement relief having values between $1.5-7.9 \mathrm{~m}, 64.5-503.9 \Omega \mathrm{m}, 5.2-15.7 \mathrm{~m}$ and $136.8-160.7 \mathrm{~m}$ respectively. Prospectivity ranking map was generated from these parameters and was used to rank the area around the VES stations. The results show that the most prospective areas with the highest ranking of 8,7 and 6 correspond to areas around VES station 6,1 and 2 respectively, restricted to the Eastern - Northwestern region of the study area.
\end{abstract}

\section{DOI: $\underline{\text { https://dx.doi.org/10.4314/jasem.v21i7.12 }}$}

Copyright (C) 2017 Salami and Ogbamikhumi is an open access article distributed under the Creative Commons Attribution License (CCL), which permits unrestricted use, distribution, and reproduction in any medium, provided the original work is properly cited

Received 17 October 2017; received in revised form 17 November 2017; accepted 10 December 2017

Keywords: Groundwater, Vertical Electrical Sounding, Fractured basement, prospectively ranking

The ease of developing groundwater in Nigeria is restricted by the fact that most part of the country is underlain by Basement Complex rocks. (Kazeem,2007). Development of secondary porosity and permeability by weathering in such terrains bring about the occurrence of groundwater. The aquifers are inherently discontinuous; hence, the need to conduct geophysical investigation to locate areas with abundance of such fractures capable of holding economic quantity of water in place for productive borehole placement.

Various geophysical methods have been applied successfully to explore for ground water in basement terrains. Some of these methods include electrical, magnetic, electromagnetic etc. Of all these methods, electrical resistivity method has been the most widely used for groundwater exploration (Alile et al., 2008). The VES (Vertical Electrical Sounding) is an electrical resistivity method that is commonly used for depth sounding due to its simplicity and reliability.(Olawuyi and Abolarin, 2013). It is used to evaluate the vertical variation of electrical resistivity below the earth surface since the electrical resistivity of most rocks is dependent on the amount of water in the pore spaces within the rocks, the distribution of these pores and the salinity of the water in the pore spaces.

The study area is underlain by Precambrian Basement Complex rocks, characterized by low porosity and permeability. The highest groundwater yield in such terrains are found in areas where thick overburden overlies fractured zones; these zones are often characterized by relatively low resistivity values (Olorunfemi et al., 1990). Locations of such zones are valuable sites to place wells for portable groundwater production devoid of pollutants (Alabi et al., 2010). The people of this community typically depend on various forms of water source such as streams and hand dug wells known for their vulnerability to pollution, thereby making them prone to water borne diseases.(Ologe et al., 2014).

The need to provide portable water sources for Ihievbe Ogben community, to reduce their adverse health exposure level constitutes the objevtive of this study.

\section{MATERIALS AND METHODS}

The geophysical prospecting method adopted for this study is the Vertical Electrical Sounding (VES) techniques of the Electrical resistivity method deploying the Schlumberger array configuration. The ABEM SAS-1000 Terrameter along with necessary accessories equipment were used. According to (Olawuyi and Abolarin, 2013), in the schlumberger array, the spacing between the potential electrode (MN) was recommended for reliable readings, not to exceed $40 \%$ of half the distance of the spacing (AB) of the current electrodes. The current survey comprise of 8 VES stations (Figure 2), acquired 
deploying the schlumberger array with a maximum current electrode separation $(\mathrm{AB} / 2)$ of $100 \mathrm{~m}$.

The apparent resistivity electrical response measured from the field were then plotted on double logarithmic graph sheet against half the currentelectrode spacing $(\mathrm{AB} / 2)$ to produce the observed field curve which was eventually initially interpreted by partial curve matching to give an estimate of the layers resistivity and thickness. These results serve as starting point for the iterative computer assisted interpretation that was later done. Geo-electric section and Subsurface maps were generated using parameter such as the overburden thickness, weathered/Fractured zone thickness, Resistivity response of the weathered/ Fractured layer, Basement relief, Clay thickness and Prospectively ranking, to aid our interpretation and evaluation of

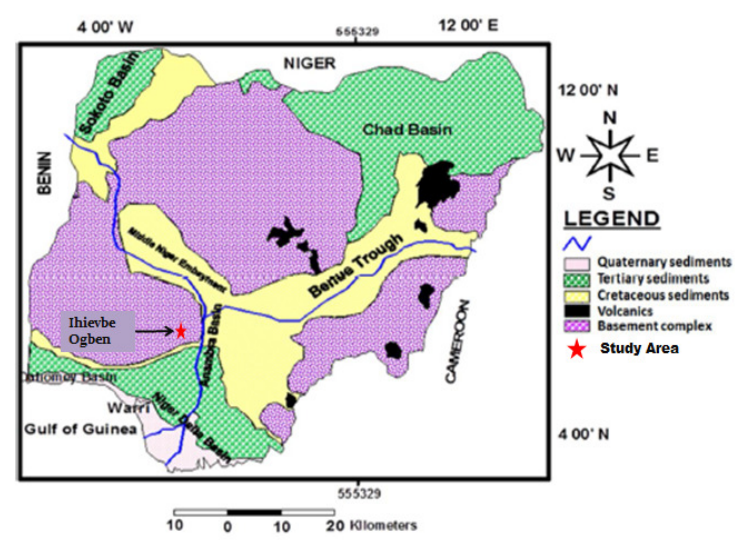

Fig1: Geological Map showing major rock distribution in Nigeria and the position of the study area. (Modified after

\section{RESULTS AND DISCUSSIONS}

Eight (8) depth sounding points using Schlumberger array were conducted within the study area. The aquired field data and interpreted results are presented in tables, charts, VES profile curves, geoelectric sections and subsurface maps. Hydrogeological parameters evaluated to understand the groundwater potential around the study area include basement relief, overburden thickness, fractured zone thickness, fractured zone isoresistivity distribution. Four geoelectric layers were interpreted applying both partial curve matching and computer software iterative technique (Table 1). These layers correspond to the top soil, clay, weathered/fractured basement and fresh basement typical of the geological layering characteristics of the basement terrain. the ground water potential of Ihieve Ogben Community.

\section{STUDY AREA}

The study area is Ihievbe Ogben, and it is located in Edo State, southwestern Nigeria. It lies between latitude $7^{0} 09^{\prime} 45^{\prime \prime}$ and $7^{0} 11^{\prime} 40^{\prime \prime} \mathrm{N}$ and longitude $6^{0}$ $08^{\prime} 45^{\prime \prime}$ and $6^{\circ} 11^{\prime} 15^{\prime \prime}$ (Figure 2). The study area falls within the Igarra schist belt, which is part of the South Western Nigeria Basement Complex rocks (Figure 1). The Basement complex rocks underlying the study area is classified into four main lithologies (Oyawoye, 1972), namely: The Older Granite; The Migmatite Complex; The Metasediment series; Miscellaneous rock rock types.

The mapped lithologies around the VES vicinity are basically typical of the rocks types found within the Igarra schist belt. Therefore the study area falls within the third lithological group classification of Oyawoye

1972.

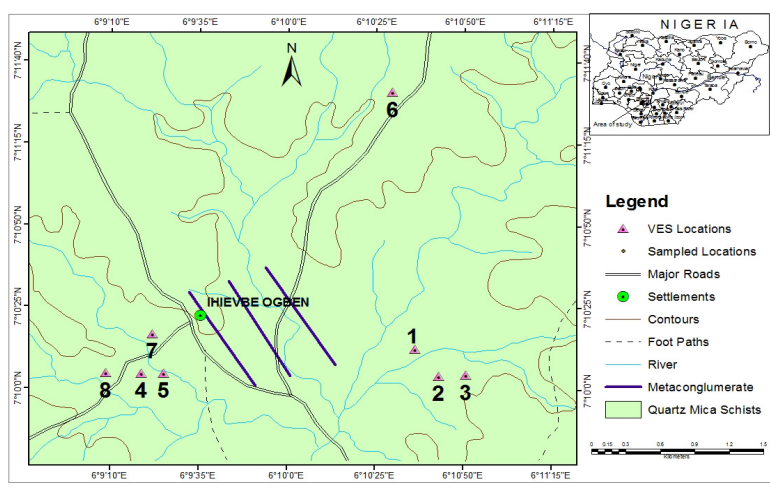

Fig 2: Map showing rock types and location of the study area with VES station distribution

The geo electrical parameters interpreted from the 8 VES stations are present in Table 1. Four different curve types were interpreted; $\mathrm{KH}(\mathrm{P} 1<\mathrm{P} 2>\mathrm{P} 3<\mathrm{P} 4)$, HA $(\mathrm{P} 1<\mathrm{P} 2>\mathrm{P} 3<\mathrm{P} 4), \mathrm{QH}(\mathrm{P} 1>\mathrm{P} 2>\mathrm{P} 3<\mathrm{P} 4)$ and $\mathrm{QA}(\mathrm{P} 1>\mathrm{P} 2>\mathrm{P} 3<\mathrm{P} 4)$ (Figure 4$)$. The interpreted VES results were used to model the subsurface rock in 2-D geo-electric sections. (Figure 5). The model gave insights into the geometry and thickness variation of the various lithologic units along the cross section. Four major layers that correspond comparatively to the top soil, clay, weathered/ fractured basement and fresh basement, typical of the four basic lithological units defined in basement hydrogeology were interpreted, (Bayode et al., 2005). From Table 1, it is observed that for more than 50\% of the sounding points, the resistivity of the bedrock is not less than $5000 \Omega \mathrm{m}$. As demonstrated by Hezell et al.(Hezell et al., 1992), the bedrock can be described as incompetent and mostly fractured. 
The first layer on the geo- electric section is the top soil characterized by clayey sand with resistivity

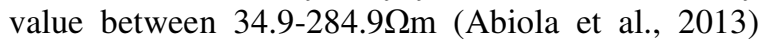
and thickness ranging between $0.44-1.20 \mathrm{~m}$. The second layer described as clay has resistivity values between $36.7-76.3 \Omega \mathrm{m}$ and thickness between 2.4$9.2 \mathrm{~m}$. The third layer is defined as the weathered basement, and constitutes the main potential aquifer

\begin{tabular}{|c|c|c|c|c|c|c|c|c|c|c|c|c|c|c|c|}
\hline \multirow[b]{2}{*}{$\begin{array}{l}\text { 总 } \\
\text { 惫 } \\
\text { 宸 }\end{array}$} & \multirow[b]{2}{*}{ Location } & \multirow[b]{2}{*}{ 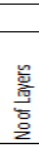 } & \multicolumn{5}{|c|}{ Specific Layer Resistivity, $\Omega \mathrm{m}$} & \multicolumn{4}{|c|}{ Layer Thickness, $\mathrm{m}$} & \multicolumn{4}{|c|}{ Depth to bottom of Layers, $m$} \\
\hline & & & $\rho_{2}$ & $\rho=$ & $\rho s$ & $\rho_{*}$ & $\rho=$ & $h_{2}$ & $h_{z}$ & $h=$ & $h_{\infty}$ & $d_{2}$ & $d z$ & $d=$ & $d_{t}$ \\
\hline 1 & $\begin{array}{l}\text { Ihievbe } \\
\text { Ogben }\end{array}$ & 5 & 50.50 & 36.71 & 8.02 & 154.97 & 278.33 & 0.58 & 2.77 & 3.86 & 7.01 & 0.58 & 3.35 & 7.21 & 14.22 \\
\hline 2 & $\begin{array}{l}\text { Ihievbe } \\
\text { Ogben }\end{array}$ & 5 & 150.01 & 36.82 & 14.76 & 64.48 & 3244.80 & 1.20 & 2.80 & 6.40 & 4.60 & 1.20 & 4.01 & 10.40 & 14.96 \\
\hline 3 & $\begin{array}{l}\text { Ihievbe } \\
\text { Ogben }\end{array}$ & 5 & 112.32 & 37.95 & 11.24 & 149.90 & 11440.0 & 0.69 & 1.62 & 1.97 & 2.94 & 0.69 & 2.31 & 4.28 & 7.21 \\
\hline 4 & $\begin{array}{l}\text { Ihievbe } \\
\text { Ogben }\end{array}$ & 5 & 129.60 & 56.11 & 145.67 & 8813.90 & 1676.20 & 0.98 & 2.59 & 1.66 & 14.69 & 0.98 & 3.57 & 5.22 & 19.91 \\
\hline 5 & $\begin{array}{l}\text { Ihievbe } \\
\text { Ogben }\end{array}$ & 5 & 34.94 & 76.27 & 10.75 & 503.90 & 13624.0 & 0.44 & 1.08 & 2.43 & 3.57 & 0.44 & 1.52 & 3.95 & 7.52 \\
\hline 6 & $\begin{array}{l}\text { Ihievbe } \\
\text { Ogben }\end{array}$ & 5 & 286.94 & 53.24 & 38.78 & 197.42 & 1914.90 & 0.99 & 1.57 & 5.18 & 7.93 & 0.99 & 2.56 & 7.74 & 15.68 \\
\hline 7 & $\begin{array}{l}\text { Ihievbe } \\
\text { Ogben }\end{array}$ & 5 & 117.22 & 49.72 & 142.00 & 1793.5 & 3380.00 & 0.98 & 2.53 & 1.48 & 4.29 & 0.98 & 3.51 & 4.99 & 9.28 \\
\hline 8 & $\begin{array}{l}\text { Ihievbe } \\
\text { Ogben }\end{array}$ & 5 & 112.75 & 44.97 & 10.21 & 153.05 & 15501.0 & 0.66 & 1.29 & 1.92 & 2.76 & 0.66 & 1.95 & 3.87 & 6.63 \\
\hline
\end{tabular}
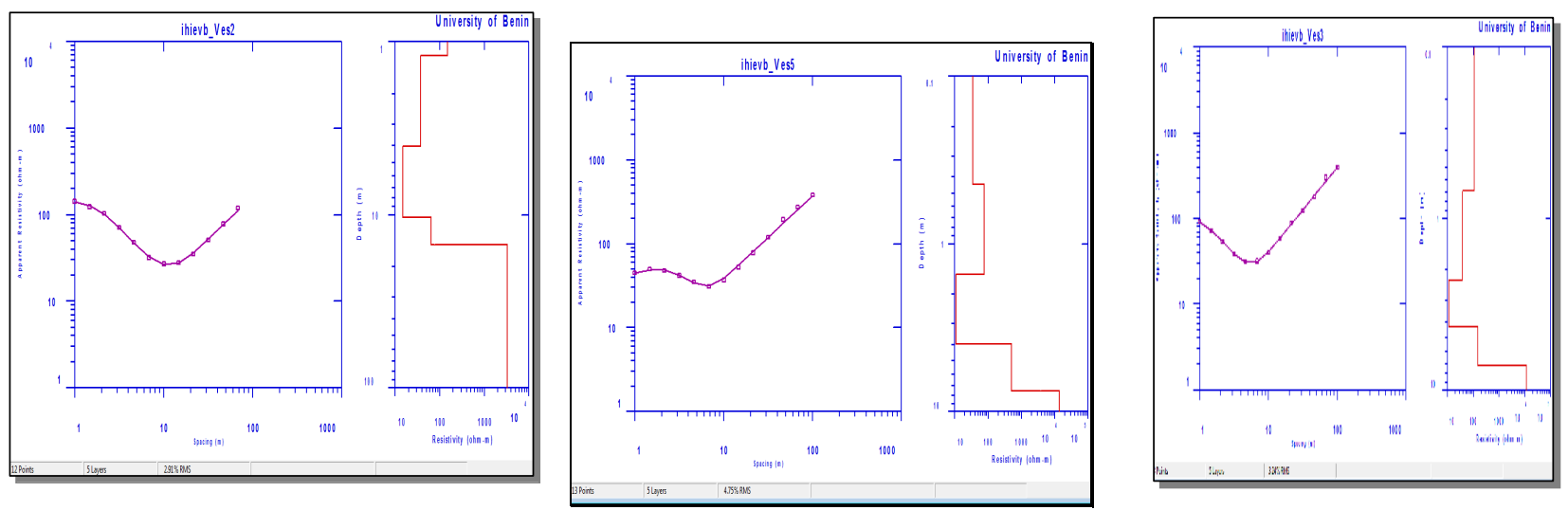

Fig 4: Some of the Software generated VES curves

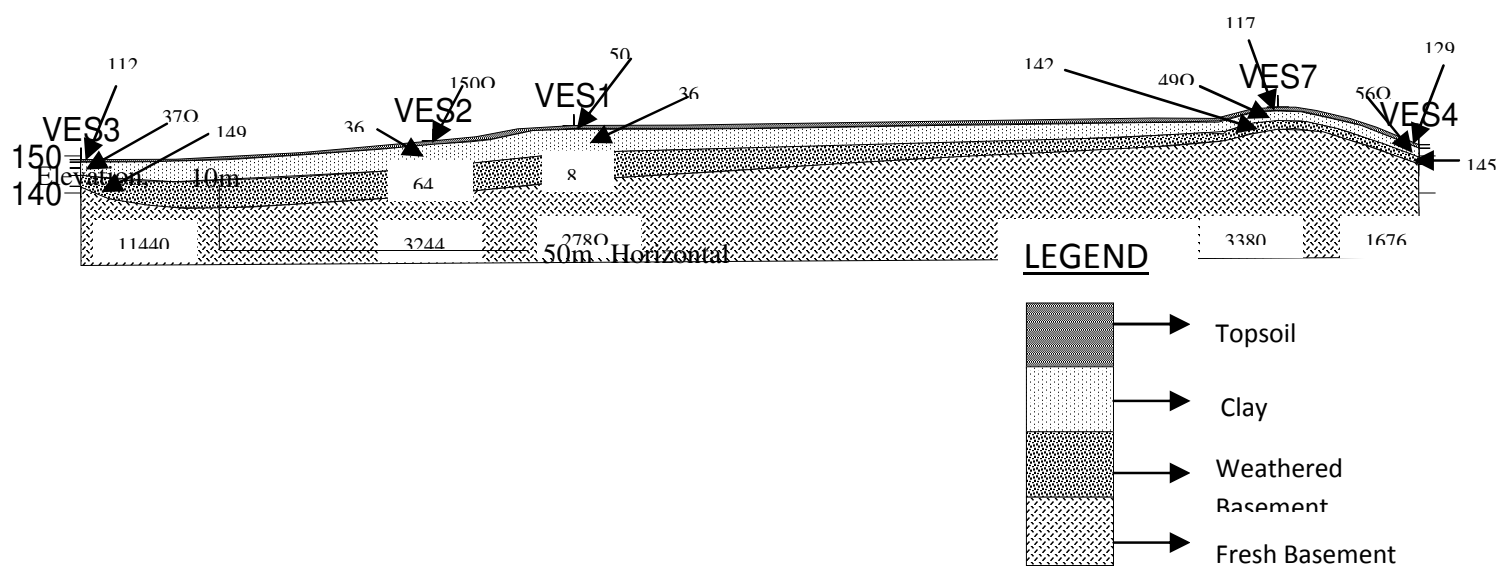

Fig 5: Northwest to Southeast cross section of VES location in Ihievbe-ogben showing VES 3,2,1,7 and 4.

Subsurface maps were generated with parameters in hydrogeological parameters, and visualization of Table2, for effective interpretation of the estimated spatial distribution of data across the study area. The 
subsurface maps generated for this study include Basement relief map, Overburden thickness maps, Weathered/fractured zone resistivity and thickness maps, Clay thickness map and prospectivity ranking map. The basement relief map was obtained by subtracting the overburden thickness from the respective VES station elevations. This is very important becauses it reveals areas of basement depression that coincide with low elevation and areas of basement highs, related to high elevation.

Table 2: Parameters used to generate subsurface maps

\begin{tabular}{|c|c|c|c|c|c|c|c|c|c|c|}
\hline & ELEV & Northings & Eastings & $\begin{array}{l}\text { Weathering } \\
\text { front/Fractured } \\
\text { zone Thickness }\end{array}$ & $\begin{array}{l}\text { Regolith/ } \\
\text { Overburden }\end{array}$ & $\begin{array}{l}\text { Basement } \\
\text { Topography }\end{array}$ & $\begin{array}{l}\text { Clay } \\
\text { Thickness }\end{array}$ & $\begin{array}{l}\text { Productivity } \\
\text { Ranking }\end{array}$ & $\begin{array}{l}\text { Depth to } \\
\text { top of } \\
\text { fractured } \\
\text { zone }\end{array}$ & $\begin{array}{l}\text { Fractured } \\
\text { window } \\
\text { resistivity }\end{array}$ \\
\hline VES1 & 162 & 25812.6 & 22177.1 & 7.01 & 14.22 & 147.78 & 3.86 & 7 & 7.21 & 154.97 \\
\hline VES2 & 154 & 25811.6 & 22181.6 & 4.56 & 14.96 & 139.04 & 9.2 & 6 & 10.40 & 64.48 \\
\hline VES3 & 144 & 25806.9 & 22188.7 & 2.94 & 7.21 & 136.79 & 3.59 & 4 & 4.27 & 149.9 \\
\hline VES4 & 153 & 25823.0 & 22158.0 & 1.66 & 5.22 & 147.78 & 2.59 & 2 & 3.56 & 145.67 \\
\hline VES5 & 157 & 25824.0 & 22165.9 & 3.57 & 7.52 & 149.48 & 2.43 & 5 & 3.95 & 503.9 \\
\hline VES6 & 158 & 25831.3 & 22172.2 & 7.93 & 15.68 & 142.32 & 5.18 & 8 & 7.75 & 197.42 \\
\hline VES7 & 170 & 25815.0 & 22160.0 & 1.48 & 9.28 & 160.72 & 2.53 & 1 & 7.8 & 142 \\
\hline VES8 & 159 & 25821.0 & 22187.0 & 2.76 & 6.63 & 152.37 & 3.21 & 3 & 3.87 & 153.05 \\
\hline
\end{tabular}

Areas of basement depression are important potential prospective zone with good groundwater potential. This implies that areas with the greatest depression has the potential of having the greatest overburden thickness, fractured zone thickness and clay thickness, which are very important hydrogeological parameters to consider in groundwater prospectivity. The basement relief map in Figure 7 shows the basement elevation that falls in the range $137-161 \mathrm{~m}$. It aslo reveals the eastern-northwestern streatch as having the least elevation of less than $155 \mathrm{~m}$, which coincide with the region of greatest basement surface depression in the study area.

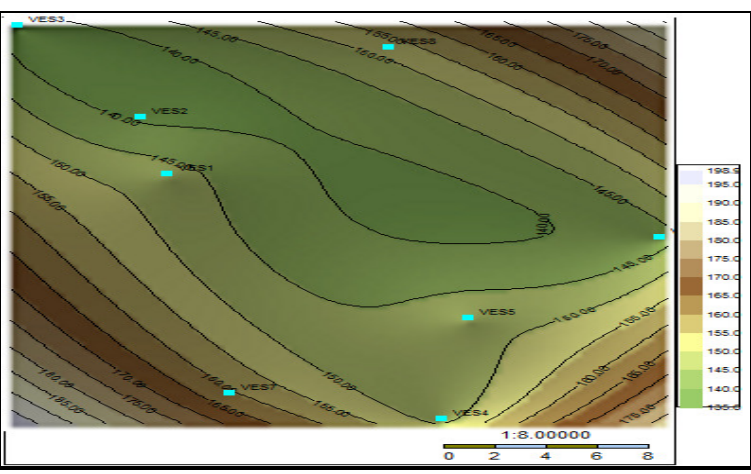

Fig 7: Basement relief map

Figure 9 is the map of the weathered/ fractured layer, considered to be the main aquiferous zone in the study area(Wright, 1992) . The thickness vary between $1.5-8 \mathrm{~m}$, with the eastern and western part having the greatest thickness around VES1 and VES6. The most weathered part of the basement occurs around VES1, VES2 and VES6, which corresponds to the central part of the map, trending East- West of the study area. Generally, the thickess falls below $10 \mathrm{~m}$ and therefore boreholes drilled into
The overburden represent all materials above the presumed fresh basement (Abiola et al. 2013). As a rule of thumb, regions with thick overburden always coincide with basement depression. Such areas are known to have high groundwater potential (Okhue and Olorunfemi, 1991). The thickness of the overburden as shown in Figure 8 varies between 5.2$15.7 \mathrm{~m}$. The thickest area being around the central region of the study area where VES 1 and VES 6 are located, and the northcentral region where VES 2 was stationed. The nothern and southern region of the map area have the thinest overburden.

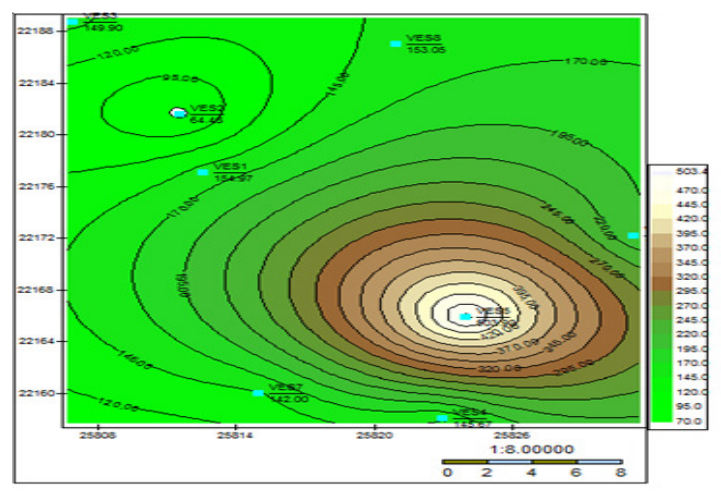

Fig 8: Overburden thickness

this aquiferous zone may lack the potential to serve as commercial sources of water, but they can sufficientlyserve domestic purposes.

The resistivity values of the weathered zone is one of the most important hydrogeological parameters to be considered for groundwater prospectivity in basement terrain because it gives an insight as to whether the fractures are water bearing or not. The resistivity value of this layer varies between 64.5 and $504 \Omega \mathrm{m}$, and the distribution of values in most part of the map 


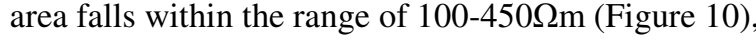
considered as having a good potential for

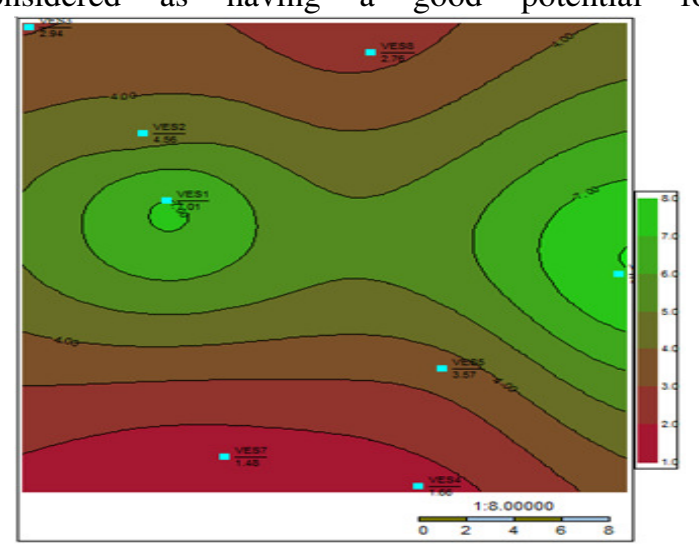

Fig 9: Fracture zone thickness map

The clay thickness map in Figure 11 shows that the northwestern portion of the map area has the greatest thickness of about $9 \mathrm{~m}$, while the northern and southern part has values less than $3 \mathrm{~m}$. The thickness range between $3.5-10 \mathrm{~m}$ covers the eastern northwestern stretch of the map within the vicinity of VES 1, 2 and 6. The implication and importance of clay thickness evaluation lies in its natural filtering effect of water infiltrating and percolating into the ground water thereby protecting the water from contaminant that may result from anthropogenic activities at the surface or near surface.

The natural Iso-electric response and thickness of the weathered/fractured layer are among the most important parameters to consider in evaluating the ground water potential in a basememt complex terrain (Bala and Ike, 2001). The ground water groundwater (Adiat et al., 2009).

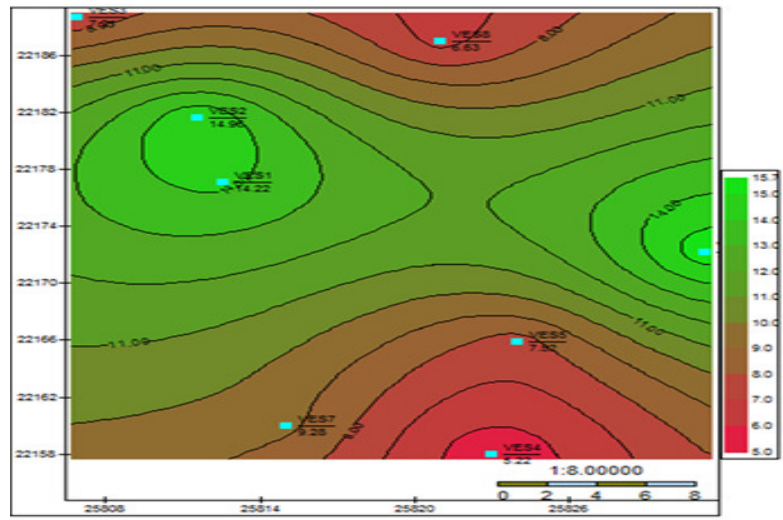

Fig 10: Fracture zone Resistivity map

potential is ranked between 1 and 8 , with 8 being the region with the highest groundwater potential and 1 the least. Figure 12 shows the ranking map of the prospective areas established by considering the following key parameters condition, to define the best prospective area: Weathered/fractured basement thickness greater than $4 \mathrm{~m}$, resistivity values between 64.5 and $503.9 \mathrm{~m}$, overburden thickness greater than $9 \mathrm{~m}$, Clay thickness greater or equal to $3.5 \mathrm{~m}$ and basement relief elevation less than $150 \mathrm{~m}$.

Area around VES6, VES1 and VES2 best meet most of the aforementioned hydrogeological conditions. Hence, they are ranked 8,7, and 6 respectively as the best prospective areas and spans the eastern - north western zone of the study area. This zone described above represent the best location to site a borehole for groundwater production (Figure 12) .

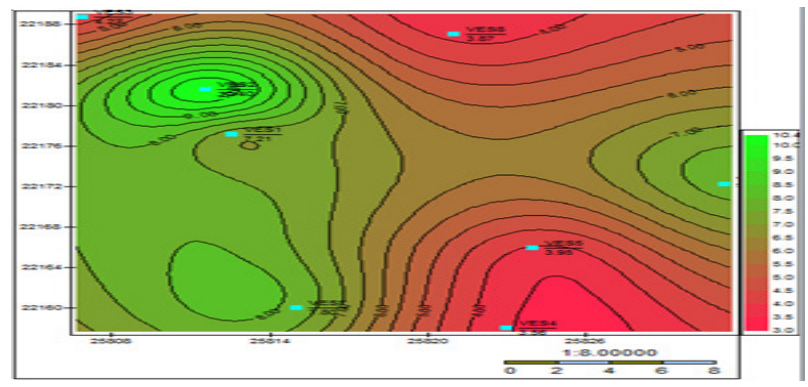

Fig 11: Clay thickness Map

Conclusion: The importance and application of the Electrical resistivity method for groundwater evaluation in a basement area has been demonstrated in this study carried out within basement terrain of the Ihievbe Ogben community. The eight VES interpreted revealed four basic subsurface layers in

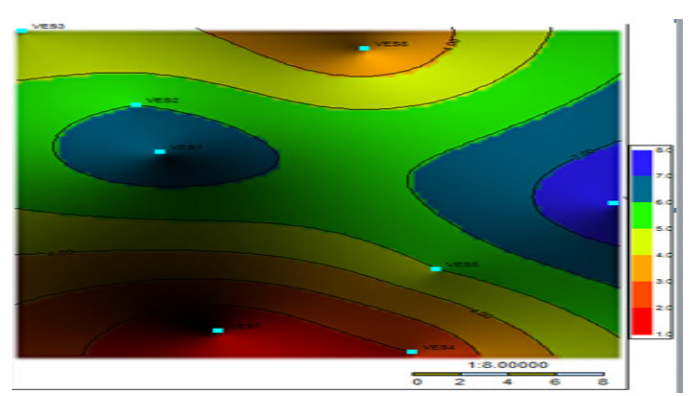

Fig 12: Prospectivity ranking map

the community. They include the top soil, clay layer, weathered/fractured basement and the fresh basement. The weathered/fractured basement was identified as the water bearing layer as demonstrated by Olurunfemi et al. 1990. The study revealed the eastern- northeastern zone to be the most prospective 
region with the best hydrogeologic conditions for borehole siting especially around VES 6,1 and 2 . The northern and southern region has the least potential for groundwater prospectivity.

It is important to state here that although the overburden and clay thickness in these proposed locations are favourable for the natural filtering process for good groundwater quality, (Alabi et al., 2010), the thickness of the weathered basement across the study area (less than 10m) is not so favourable enough for commercial borehole project. Therefore, the community should only be considered for domestic borehole development.

\section{REFERENCES}

Abiola, O; Ogunribido, T. H. T; Omoniyi, B. A; Ikuepamitan, O (2013). Geoelectric assessment of groundwater prospects in Supare Estate, Supare Akoko, Southwestern, Nigeria. Geosciences. 3(1): 23-33.

Adiat, K. A. N; Olayanju, G. M; Omosuyi, G. O; Ako, B. D (2009). Electromagnetic profiling and electrical resistivity soundings in groundwater investigation of a typical Basement Complex-a case study of Oda Town Southwestern Nigeria. Ozean Journal of Applied Sciences. 2(4): 333359.

Alabi, A. A; Bello, R; Ogunghe, A. S; Oyerinde, H. O (2010). Determination of groundwater potential in Lagos State University, Ojo; using geo-electric methods (Vertical electrical sounding and horizontal profiling). 2(5): 68-75.

Alile, M. O; Jegede, S. I; Ehigiator, O. M (2008). Underground water exploration using electrical resistivity method in Edo State, Nigeria. Asian Journal of Earth Sciences. 3(1):57-61.

Bala, A. E; Ike, E. C (2001). The aquifer of the crystalline basement rocks in Gusau area, Northwestern Nigeria. Journal of Mining Geolog. 37(2): 177-184.
Bayode, S; Ojo, J. S; Olorunfemi, M. O (2005). Geoelectric characterisation of aquifer types in the Basement Complex of part of Osun State, Nigeria. Global Journal of Pure and Applied Sciences. 12: 377-385.

Hazell, J. R. T; Cratchley, C. R; Jones, C. R. C (1992). The hydrogeology of crystalline aquifers in northern Nigeria and geophysical techniques used in their exploration. Geological Society, London, Special Publications. 66(1): 155-182.

Kazeem, A. S (2007). Lithostratigraphy of Nigeria. An Overview. Workshop on Geothermal Reservation Engineering, Stanford University, Stanford, California. 32:1-4.

Olorunfemi, M. O; Okhue, E. T (1991). Electrical resistivity investigation of a typical basement complex area-the Obafemi Awolowo University Campus case study. Journal of Mining Geology. 27(2): 63-69.

Olawuyi, A. K.; Abolarin, S. B (2013). Evaluation of vertical electrical sounding method for groundwater development in basement complex terrain of west-central Nigeria. Nigerian Journal of Technological Development. 10(2):22-28.

Ologe, O; Bankole, S. A; Adeoye, T. O (2014). GeoElectric Study for Groundwater Development in Ikunri Estate, Kogi West, Southwestern Nigeria. Ilorin Journal of Science. 1: 154-166.

Olorunfemi, M. O; Ojo, J. S; Akintunde, O. M (1990). Hydro-geophysical evaluation of the groundwater potentials of the Akure metropolis, southwestern Nigeria. Journal of mining and Geology. 35(2): 207-228.

Oyawoye, M. O (1972). The basement complex of Nigeria. African geology.

Sharma, P. V (1997). Environmental and engineering geophysics. Cambridge university press.

Wright, E. P (1992). The hydrogeology of crystalline basement aquifers in Africa. Geological Society, London, Special Publications. 66(1): 1-27. 